\title{
Erratum to: Different expression of $\beta$ subunits of the KCa1.1 channel by invasive and non-invasive human fibroblast-like synoviocytes
}

\author{
Zoltán Pethő ${ }^{1,2}$, Mark R. Tanner ${ }^{1,3}$, Rajeev B. Tajhya ${ }^{1,4}$, Redwan Huq ${ }^{1,4}$, Teresina Laragione ${ }^{5}$, Gyorgy Panyi², \\ Pércio S. Gulko ${ }^{5}$ and Christine Beeton ${ }^{1,6,7^{*}}$
}

After publication of this article [1], it was noticed that the Ethical Considerations subsection within the Methods section was worded such that it suggested that the Feinstein Institute Tissue Donation Program collected synovial tissues and isolated FLS. For clarity, the Ethical Considerations statement should instead be read as, "De-identified synovial samples were collected for research under the approval of the Institutional Review Board (IRB) of the Feinstein Institute for Medical Research. All patients provided written consent to have their tissues, RNA, DNA, and cells studied. The consent forms are held by the Feinstein Institute Tissue Donation Program; Dr. Gulko's group isolated and characterized the FLS and banked them for research. The IRB at Baylor College of Medicine has established that the work conducted there did not constitute human research since the samples were already banked for research and were de-identified; thus could not be traced back to their donor."

\section{Author details}

'Department of Molecular Physiology and Biophysics, Mail Stop BCM335, Room S409A, Baylor College of Medicine, Houston, TX 77030, USA. ${ }^{2}$ Department of Biophysics and Cell Biology, Faculty of Medicine, University of Debrecen, Debrecen 4032, Hungary. ${ }^{3}$ Interdepartmental Graduate Program in Translational Biology and Molecular Medicine, Baylor College of Medicine, Houston, TX 77030, USA. ${ }^{4}$ Graduate Program in Molecular Physiology and Biophysics, Baylor College of Medicine, Houston, TX 77030, USA. ${ }^{5}$ Division of Rheumatology, Icahn School of Medicine at Mount Sinai, New York, NY 10029, USA. ${ }^{6}$ Biology of Inflammation Center, Baylor College of Medicine, Houston, TX 77030, USA. ${ }^{7}$ Center for Drug Discovery, Baylor College of Medicine, Houston, TX 77030, USA.
Received: 16 May 2016 Accepted: 17 May 2016 Published online: 01 June 2016

\section{Reference}

1. Pethő Z, Tanner MR, Tajhya RB, Huq R, Laragione T, Panyi G, Gulko PS, Beeton C. Different expression of $\beta$ subunits of the KCa1.1 channel by invasive and non-invasive human fibroblast-like synoviocytes. Arthritis Res Ther. 2016;18:103. doi:10.1186/s13075-016-1003-4.

\footnotetext{
* Correspondence: beeton@bcm.edu

'Department of Molecular Physiology and Biophysics, Mail Stop BCM335, Room S409A, Baylor College of Medicine, Houston, TX 77030, USA

${ }^{6}$ Biology of Inflammation Center, Baylor College of Medicine, Houston, TX 77030, USA

(c) 2016 Pethő et al. Open Access This article is distributed under the terms of the Creative Commons Attribution 4.0 International License (http://creativecommons.org/licenses/by/4.0/, which permits unrestricted use, distribution, and reproduction in any medium, provided you give appropriate credit to the original author(s) and the source, provide a link to the Creative Commons license, and indicate if changes were made. The Creative Commons Public Domain Dedication waiver (http://creativecommons.org/publicdomain/zero/1.0/) applies to the data made available in this article, unless otherwise stated.

Submit your next manuscript to BioMed Central and we will help you at every step:

- We accept pre-submission inquiries

- Our selector tool helps you to find the most relevant journal

- We provide round the clock customer support

- Convenient online submission

- Thorough peer review

- Inclusion in PubMed and all major indexing services

- Maximum visibility for your research

Submit your manuscript at www.biomedcentral.com/submit 